\title{
Lessson-Learned: Participatory Action Research Project with Upland Smallholder Farmers Practicing Cropland Agroforestry System in Wonogiri Regency to Support National Food Security
}

\author{
Rudy Nur Hidayah ${ }^{1}$, Wiyono ${ }^{2}$, Oka Karyanto ${ }^{3}$ \\ ${ }^{1,3}$ Laboratory of Ecosystem Complex Process, Faculty of Forestry, Universitas Gadjah Mada \\ ${ }^{2}$ Department of Bioresources Technology and Veterinary, Vocational School, Universitas Gadjah Mada
}

Received: 3 January 2021; Revised: 15 October 2021; Accepted: 25 October 2021

\begin{abstract}
Indonesia government pays little attention to address impending threat of the existences of upland smallholder farmers due to insufficient farm income. This condition poses an imminent threat to national food security. One of the initiatives to address the condition is participatory action research project conducted by Faculty of Forestry UGM with 12 upland smallholder farmers in Wonogiri regency from 2016 to 2018. The result of the participatory action research project showed that although the 12 smallholder farmers practice cropland agroforestry system in marginal land, their increased rice production could improve farm income, be similar in rice field and support national food security. Therefore, this study aimed at investigating lesson-learned of the participatory action research project. This study was conducted on January-March 2020, used participant observation and semi-structure interview methods to collect data from the 12 smallholder farmers. After the collected data were analyzed by descriptive method, this study founded four points of lesson-learned including (1) finding a responsive smallholder farmer group; (2) minimizing negative role of local elite; (3) maximizing positive role of local elite; (4) implementing modified technology package.
\end{abstract}

Keywords: PAR; smallholder farmer; food security

How to cite:

Hidayah, R. N., Wiyono, \& Karyanto, O. (2021). Lessson-Learned : Participatory Action Research Project with Upland Smallholder Farmers Practicing Cropland Agroforestry System in Wonogiri Regency to Support National Food Security. Habitat, 32(3), 141-153. https://doi.org/10.21776/ub.habitat.2021.032.3.16

\section{Introduction}

Smallholder farmers generally defined as one of farmer classifications operating less than 2 hectare of farmland produce above $70 \%$ of total global food (Wolfenson, 2013; FAO, 2014) so that their existences plays a key role in achieving global food security. On the contrary, the existence of the smallholder farmers constantly confronts issues when farm income is unable to meet daily needs besides their household food consumption (FAO. 2017). Their insufficient farm income greatly affects the degree of intensification of farming practices as smallholder farmers commute to city and other village where they work in non-agricultural sectors to earn off-farm income (Marzin et al., 2016). Furthermore, the

${ }^{*}$ Correspondence Author

E-mail: wiyono.putro@ugm.ac.id disappearance of smallholder farmers will arise gradually when their off-farm income satisfy daily need including household food consumption (Fan et al., 2015). Consequently, these phenomena menace global food security when world population will increase rapidly by 2050 (Alexandratos and Bruinsma, 2012) and will demand for high food consumption.

The gradual disappearance of smallholder farmers posing an impending threat to global food security become crucial issues at worldwide (FAO, 2011), so that every states must address it by engaging them in food-security projects for increasing their food crop production and farm income. To date Indonesia government, for example, has concerned the issue by launching many in food-security projects. In 1987 the green revolution project, one of food-security projects in lowland area of Java island, successfully doubled rice production so that main sources of national food supply was adequate to meet food 
consumption (Las, 2009). Although the green revolution project brought Indonesia to realize national food security and even help address problem of global food supply, it was mostly captured by the local elites and was not accessed by smallholder farmers (Suseno and Suyatna, 2007; Welker, 2012).

After the green revolution project, most of the food-security projects have been focused on rice field in lowland areas of Java island, where the conversion of rice field into house and building reached 167.150 hectare from 1999 to 2002 (Agus and Irawan, 2006) and it has recently progressed owing to increased population that demand for houses and building. Meanwhile, farmland in upland area constitutes 87 percent or around 50 million ha of the total geographical area in Indonesia (Asian Productivity Organization, 2004) and has been mostly neglected by Indonesia government to acquire the projects. After green revolution, Indonesia has a tendency to import rice (Silalahi et al., 2019), so that the recurring foodsecurity projects has failed to solve national food insecurity. Moreover, they pay little attention to address impending threat of existences of smallholder farmers, especially in upland area.

Upland smallholder farmers cultivating potential farmland to overcome Indonesia food insecurity need to support non-governmental initiative to boots rice production so that they have sufficient farm income and their disappearance are unlikely to occur. One of the initiatives is participatory action research project with upland smallholder farmers. As smallholder farmers are one of farmer classifications (Khalil et al., 2017) this initiative is also called by Farmer Participatory Research (FPR) project (Selener, 1997). Fisher (2006) and Selener (1997) state that FPR project is one of bottom-up initiatives to achieve sustainable agricultural development in the project areas. Furthermore, FPR project is applicable for developing appropriate solution to concrete problem because objects of research project such as smallholder farmers actively involve the whole activities in FPR project (Huizer, 1997).

This study aimed at investigating the lesson-learned from the participatory action research project with 12 upland smallholder farmers in Wonogiri regency or FPR project conducted by faculty of Forestry Universitas Gadjah Mada (UGM) from 2016 to 2018. There was little scientific publication of the lessonlearned from FPR project support national food security. Furthermore, 12 upland smallholder farmers engaging in the participatory action research project practice cropland agroforestry system in marginal land without intensive irrigation being similar in rice field so that the lesson-learned could be new and valuable information to other organizations such as government especially Indonesia government to begin large scale of food-security project in upland area.

\section{Theoretical Underpinning}

Over the past 15-20 years, numerous research institutions besides non-government organization have carried out FPR projects to solve issues on farmers in many specific areas and to realistically contribute to local-level agricultural development. In Manupali of Northern Mindano in Philippine, research institutions have reported that due to FPR project, farmers can minimize soil erosion and increase vegetable production such as tomato (Poudel et al., 2000). In six districts of Khasmir in India, farmers have achieved high rice production and good farm income because they have collaborated with research institutions to conducted participatory action research projects (Najeb et al., 2017).

In Garut regency of West Java province in Indonesia, sustainable and self-sufficient farming practice can be implemented by the farmers after their joining in the participatory action research project (Nugraha et al., 2019). Furthermore participatory action research project in South Sulawesi Indonesia found that the high adoption of transfer of technology can be occur of it fulfil the needs of the farmers and the outcome of its can improve productivity of cattle and self-help of group (Habibie et al., 2002).

The process of participatory action research with farmers or FPR project also provide lessonlearned to be recommended to national agricultural development policy and projects (German et al., 2012), when result of FPR projects can assist agricultural development in the project areas. The lesson-learned from successful participatory action research projects engaging in participants such as farmers can be valuable to nonparticipants including community and researchers (Fisher, 2006; McHugh and Kowalski, 2009). Due to the important process of FPR projects, some previous international studies have reported lesson-learned (Dolinska et al., 2018; Hoffmann et al., 2007; Mendez et al., 2017; 
Mwaseba et al., 2014). Meanwhile, there are also tow national studies publishing the lesson-learned of FPR projects in Garut regency (Nugraha et al., 2019) and South Sulawesi (Habibie et al., 2002).

\section{Research Method}

This study was conducted in two villages of Wonogiri regency in central Java provinces, Poluton Kulon and Polutan Wetan, on JanuaryMarch 2020. Geographically, the villages represent upland areas in Indonesia. The two selected villages are place where 12 upland smallholder farmer engaging in participatory action research project initiated by Faculty of Forestry in UGM from 2016 to 2018.

The object of this study was 12 upland smallholder farmers joining in participatory action research project or 12 FPR participants. Based on their domicile, 7 FPR participants and 5 FPR participants are in Polutan Wetan and Polutan Kulon respectively. Whereas, 6 upland smallholder farmers taking no part in participatory action research project or 6 FPR nonparticipants were used as the comparative object of this study. Of 6 FPR nonparticipants, 4 FPR nonparticipants and 2 FPR nonparticipants dwell in Polutan Kulon and Polutan Wetan respectively.

Although every state has different category of smallholder farmers (Khalil et al., 2017), under the definition of smallholder farmers in Java island of Indonesia (Sajogyo, 1977; Susilowati and Maulana, 2012), the whole objects of this study are categorized as smallholder farmer. This is because they own less than or equal to 0,5 hectare of farmland for yielding food crops. Additionally, the small farmland of 6 FPR nonparticipants and 12 FPR participants are marginal land and grown rice as food crops surrounded by teak trees as the farm border. This condition in small farmland showed that 6 FPR nonparticipants and 12 FPR participants produce rice annually and teak timber in decided time. According to definition of cropland agroforestry system stated by Abedin et al (1991) in Chakraborty et al (2015), description of activities performed by both 6 FPR nonparticipants and 12 FPR participants in their farmland is cropland agroforestry practice.

This study used a qualitative approach and two types of data, primary and secondary data. Primary data comprised (1) experience of taking part in action research project with 12 upland smallholder farmers or FPR project from 2016 to 2018; (2) the present activities influenced the FPR project; (3) and perspective relating to further food security project for Indonesia government. Secondary data was information from report of FPR project conducted by faculty of Forestry UGM.

Primary data were collected by simultaneously carrying out participant observation and semi-structure interview to 12 FPR participants. According to Reeves et al., (2013), participant observant is a research methods that not only observe object of study but also engage in daily activities of the subject so that hidden field data can be identified and gathered in this study. As comparison of the primary data, 6 FPR nonparticipants were also observed and interviewed so that this study investigated data comprehensively. The whole primary data collected from 12 FPR participants and 6 FPR nonparticipants were analyzed descriptively and discussed comprehensively by using relevant theoretical references and approach.

\section{Results and Discussion}

\subsection{Overview of Participatory Action Research Project}

Participatory action research project had been executed by fifteen participants; (1) two researchers in laboratory of Ecosystem Complex Process at faculty of Forestry UGM; (2) one researcher from faculty of Agriculture UGM; (3) and 12 upland smallholder farmers from Polutan Wetan and Polutan Kulon, villages of Wonogiri regency taking part or 12 FPR participants. The participants had used collaborative method to perform the action research project from October 2016 to March 2018.

According to Ponzio et al (2013), when applying collaborative method, researchers and farmers have to be synergy to conduct four stages in action research project. The four stages include (1) problem identification; (2) search for solution; (3) implementation of the solution with on-farm experimentation; (4) evaluation of on-farm experimentation. Due to the requirement of collective method and the lack of time from the three researchers in the field, a field research assistant had been employed to assist the researchers intensively communicate and work with 12 upland smallholder farmers in the action research project.

The aim of participatory action research project with 12 upland smallholder farmers or FPR project was to increase, in a sustainable manner, their farm incomes. 12 upland 
smallholder farmers besides participants were object of the FPR project so that the key to achieve goal had to improve their cropland agroforestry practices. Because the result of their cropland agroforestry practices was rice and teak timber to generate income, among fifteen participants including field research assistant in the FPR project had undertaken four stages, in collaborative manner, to boost production of rice and teak timber. This study solely reviewed rice production so that the four stages were described how among four participants in FPR project pursued increased rice production and farm income of 12 upland smallholder farmers.

\subsubsection{Stage of Problem Identification}

12 FPR participants with field research assistant had held two Forum Group Discussion (FGD) and farm survey from October 2016 to February 2017. Three researchers had communicated with 12 FPR participants to identify problem of insufficient farm income and low rice production over two FGD periods, although their communication had been facilitated by field research assistant. After two FGD, 12 FPR participants with field research assistant had done farm survey in their farmland to collect data regarding type soil, rice planting system, rice varieties, rice production, and farm income. The data had supported to statement of 12 FPR participants in two FGD and had been used to discuss in stage of searching solution.

\subsubsection{Stage of Searching Solution}

Field research assistants facilitating three researchers had had long discussion with 12 FPR participants to determine ideal solution based on the result of previous activities in problem identification. This discussion had taken place on March-April 2017 and had concluded that ideal solution was to implement modified technology packages conducted by 12 FPR participants with field research assistants in their farmland.

Three were four items in the modified technology packages: (1) one of high-yielding varieties of rice seed, Situpatengang, (2) appropriate application of chemical fertilizer, (3) Legowo 4:1 row planting system and (4) rice seed planting system. The items were combination of appropriate technology package in lowland rice filed and traditional method of planting rice in upland area.

Another ideal solution in this stage was to assist 12 FPR participants by providing appropriate application of chemical fertilizer, Situpategang and practical guidance of Legowo 4:1 row planting system. This solution was main duty for three researchers facilitated by a field research assistant.

\subsubsection{Stage of Implementation of the Solution with On-farm experimentation}

The whole participants had implemented acceptable solution from November 2017 to February 2018. The modified technology package as one of acceptable solution was new effort so that participants especially for 12 FPR participants had carried out research in their farmland. In addition to assist implementation of the modified technology package, filed research assistant had gathered data on growth and production of Situpatengang. The data had been used to report three researchers and been discussed in the following stage. To compare the data, field research assistant simultaneously had collected growth and rice production from 6 FPR non participants in same location as 12 FPR participants.

\subsubsection{Stage of Evaluation of On-farm Experimentation}

On March 2018 after Situpatengang had been harvested by fifteen participants and field research assistants had held two FGD to evaluate implementation of the modified technology package in farmland of 12 FPR participants. In the evaluation, the whole participants had recognized that based on data collected from problem identification to on-farm experimentation, the modified technology package could increase rice production of 12 FPR participants. Furthermore, their farm income from increased rice production also had risen.

During the FPR project the detailed data to support the recognition of the whole participants presented in Table 1. As comparative data, Table 2 showed that 6 FPR nonparticipants had lower farm income and lower rice production than 12 FPR participants after on-farm experiment. 
Table 1. Rice production and farm income of 12 FPR participants

\begin{tabular}{ccccccc}
\hline No & Name & $\begin{array}{c}\text { Farmland } \\
\text { Size (ha) }\end{array}$ & $\begin{array}{c}\text { Rice Production per } \\
\text { Farmland Size (kg/ha) } \\
\text { Before On- } \\
\text { Farm } \\
\text { Experiment }\end{array}$ & $\begin{array}{c}\text { After On- } \\
\text { Farm } \\
\text { Experiment }\end{array}$ & $\begin{array}{c}\text { Farm Income (IDR) } \\
\text { Before On- } \\
\text { Farm } \\
\text { Experiment }\end{array}$ & $\begin{array}{c}\text { After On- } \\
\text { Farm } \\
\text { Experiment }\end{array}$ \\
\hline 1 & Mulyono & 0.30 & 1,180 & 2,064 & $4,331,000$ & $7,867,000$ \\
2 & Mulat & 0.25 & 860 & 1,640 & $3,101,000$ & $6,221,000$ \\
3 & Antok & 0.30 & 1,160 & 1,680 & $4,251,000$ & $6,331,000$ \\
4 & Yanto & 0.27 & 650 & 1,555 & $2,211,000$ & $5,831,000$ \\
5 & Wagimen & 0.30 & 1,175 & 1,584 & $4,311,000$ & $5,947,000$ \\
6 & Tukimin & 0.50 & 1200 & 2,400 & $4,124,000$ & $8,924,000$ \\
7 & Hadi & 0.35 & 880 & 2,128 & $3,081,000$ & $8,073,000$ \\
8 & Sukat & 0.25 & 910 & 1,560 & $3,251,000$ & $5,851,000$ \\
9 & Kirdi & 0.50 & 1,350 & 3,360 & $4,724,000$ & $12,764,000$ \\
10 & Sular & 0.30 & 960 & 1,872 & $3,451,000$ & $7,099,000$ \\
11 & Sukino & 0.20 & 570 & 1,200 & $1,941,000$ & $4,461,000$ \\
12 & Sutarto & 0.50 & 1,580 & 2,980 & $5,644,000$ & $11,244,000$ \\
\hline & Average & $\mathbf{0 , 3 3 5}$ & $\mathbf{1 , 0 3 9}$ & $\mathbf{2 , 0 0 1}$ & $\mathbf{3 , 7 0 1 , 7 5 0}$ & $\mathbf{7 , 5 5 1 , 0 8 3}$ \\
\hline
\end{tabular}

Source: Report of farmer participatory research project in Wonogiri regency

Table 2. Rice production and income of 6 FPR non-participants

\begin{tabular}{clccc}
\hline No & Name & $\begin{array}{c}\text { Farmland } \\
\text { Size (ha) }\end{array}$ & $\begin{array}{c}\text { Rice Production per } \\
\text { Farmland Size (kg/ha) }\end{array}$ & $\begin{array}{c}\text { Farm Income (IDR) } \\
\text { per Farmland Size }\end{array}$ \\
\hline 1 & Larno & 0.30 & 970 & $3,491,000$ \\
2 & Sukidi & 0.25 & 690 & $2,421,000$ \\
3 & Sulis & 0.30 & 1,160 & $4,251,000$ \\
4 & Tukino & 0.27 & 680 & $2,331,000$ \\
5 & Darmo & 0.30 & 1,120 & $4,091,000$ \\
6 & Iman & 0.25 & 990 & $3,571,000$ \\
\hline & Average & $\mathbf{0 . 2 7 8}$ & $\mathbf{9 3 5}$ & $\mathbf{3 , 3 5 9 , 3 3 3}$ \\
\hline
\end{tabular}

Source: Report of farmer participatory research project in Wonogiri regency

Considering that average rice production after on-farm experiments in Table 2 was calculated on per hectare, 12 FPR participants were almost capable of achieving rice yield per hectare in lowland rice field of Wonogiri regency published by Suranny et al (2018). Rice yield per hectare between the calculation result and the scientific publication was 6,010 kilogram and 6,470-8,010 kilogram respectively. Additionally, rice yield per hectare in the calculation result was similar to upland rice production reported by BB Padi (2018). Further, the rice yield per hectare using high-yielding varieties of rice, practicing cropland agroforestry system and originating in Indramayu regency was 6,000-7,000 kilogram.

In spite of being in marginal farmland and depending on irregular rainfall water, 12 FPR participants after implementing modified technology package in cropland agroforestry practices could increase rice yield and be almost similar to lowland rice field characterized as productive land with intensive irrigation. Besides being mainly influenced by technology packages in line with some previous research on technology adoption (Bakar et al., 2019; BB Padi, 2018; Mangilep, 2017), cropland agroforesty system affected the increased rice production. According to Nair and Garrity (2012); Hairiah et al., (2000), tree as one of components in agroforestry system can minimize soil erosion and improve soil fertile so that agroforestry practices can be option to be used in marginal farmland. For this statement, teak in cropland agroforestry system practiced by 12 FPR participants has gradually improved soil fertile until now. Furthermore, when 12 FPR participants conducted on-farm experiments, the soil fertile in their farmland was supposed in high level and thus to influence the increased rice production. 


\subsection{Six Points of Lesson-Learned}

The outcome of participatory action research with 12 upland smallholder farmers or FPR project was satisfactory and promising solution to support national food security. This was because rice production per hectare after onfarm experiment in marginal farmland and cropland agroforestry system was almost similar to rice yield per hectare in lowland rice field with intensive irrigation and monoculture system. Furthermore, 12 FPR participants depended on irregular rainfall water or used rainfed system to conduct on-farm experiment.

In order to maximize the promising solution to realize food security from farmland mostly neglected by government project, finding lessonlearned from process of FPR project is key point. For this reason, after collecting data on what lesson-learned from process of participatory action research with 12 upland smallholder farmers achieve the outcome, this study found four points.

\subsubsection{Finding responsive smallholder farmers}

During field observation, 12 FPR participants continued to implement modified technology packages as new farming practices but 6 FPR nonparticipants practiced traditional farming system or common farming system in Polutan Kulon and Polutan Wetan. 6 FPR nonparticipants expressed they were disinterested to follow new farming practices like 12 FPR participants, although they had acknowledged that the new farming practices could increase rice production. Based on 6 FPR nonparticipants explanation, they were frightened to take risk when applying new farming practices so that they were unresponsive to participate in every project such as FPR project to change their common farming practice. Conversely, 12 FPR participants expressed that they were responsive to take part in every projects demonstrating new farming practices to increase rice production and farm income because they were brave to take risk. Further, their bravery appeared since they had recognized that their farm income from rice production were unable to satisfy their daily needs over the years when they were unresponsive to engage in projects such as FPR project. This recognition had come to 12 FPR participants after field research assistant had explained that their low rice productions from common farming practices posed insufficient farm income. The explanation had occurred when field research assistant had visited their home to offer FPR projects.

12 FPR participants said that they initially neglected the FPR projects after filed research assistants had offered FPR project by holding four formal meetings with the whole smallholder farmers and local elites. This condition had led to field research to use personal approach in each of their homes. Through personal approach, they could accept clear explanation of why their low rice production brought them to earn insufficient farm income. Further, due to the clear explanation 12 FPR participants understood that taking risk to make new effort such as shifting common farming practices was solution to achieve sufficient farm income. For their understanding, 12 FPR participants became responsive to involve in FPR project as one of their efforts. Conversely, 6 FPR nonparticipants still were fear to accept risk and unresponsive to involve in FPR projects, even though field research assistant had visited each of their homes to provide the clear explanation.

In current condition, 12 FPR participants also showed that they were still responsive to improve their rice production and farm income without join in project. When 12 FPR participants were followed in their farmland, they hold informal meeting without a field research assistant to decide new effort in increasing rice production. The new effort which was agreed and was implemented in their farmland was to use extra organic fertilizer from cow waste owned by local elites. Although the new effort was low risk and the cow waste was abundant in Polutan Kulon and Polutan Wetan, 6 FPR non-participants ignored it.

Smallholder farmers are commonly unresponsive to engage in projects to change their farming practices as they are fear to take risk (Henrich and Mcelreath, 2002; Mutsaers, 2007). According to Scott (1976), the reason of why smallholder farmers are frightened to implement new farming practices was their common farming practices can satisfy their household food consumption without considering huge profit from increased rice production. In order to meet shortage of daily need besides food consumption. In order to meet shortage of daily need besides food consumption, upland smallholder farmers prefer off-farm job to work on their farmland (Umanailo et al., 2018). On the contrary, Popkin (1979) states that smallholder farmers are classified as responsive farmers to join in every project to increase food crop yield as they constantly consider that huge profit from selling 
food crop yield have to be maximized and thus earn sufficient farm income. The different statements can be summarized that there are two smallholder farmer classification, subsistenceoriented smallholder farmers and commercial smallholder farmers. Due to the two categories of smallholder farmers, 12 FPR participants who became responsive to engage in FPR project was transforming from subsistence-oriented to commercial smallholder farmers, whereas 6 FPR nonparticipants remained subsistence-oriented smallholder farmers. Selener (1997) and Mendez et al. (2017) suggest that selecting right participants from various categories are crucial point to accomplish goals in the FPR project. For these understandable reason, the first important step of lesson-learned from FPR projects conducted in Wonogiri regency was that responsive smallholder farmer as right participants could be identified by using intensive personal approach to provide clear explanation about commercial farming. Thus, responsive smallholder farmers incurring low rice production and insufficient farm income could be addressed by their joining in FPR project.

In addition to find 12 FPR participants, explanation of commercial farming in personal approach was process of innovation diffusion as both 12 FPR participants and 6 FPR nonparticipants acquired innovation and thus to whether or not be adopted. Rogers (2003) describes that three are five adopter categories in diffusion process: (1) innovators, (2) early adopters, (3) early majority, (4) late majority, and (5) laggards. Regarding these categories, 12 FPR participants were early adopter because they immediately became commercial smallholder farmers after accepting the explanation of commercial farming. On the other hand, 6 FPR participants were laggards as they disrespected for explanation of commercial farming and thus to be unresponsive to take part in FPR project. This diffusion process ensured that 12 FPR participants were responsive characteristics to join in FPR project.

\subsubsection{Minimizing negative role of local elite}

Both 12 FPR participants and 6 FPR nonparticipants mentioned that the local elites dominated and themselves prioritized government projects such as providing chemical fertilizer and quality seeds. Further, the smallholder farmers only received the remaining project in inappropriate time to implement. Although government field extension helped implementation of government projects in order to be received by the smallholder farmers, the local elites used some method to convince the field extension and thus to gain benefit of government projects. One of the methods was to temporarily manipulate status of their own farmland to be smallholder farmer category. These recurring phenomena caused the smallholder farmers to feel worried about obtaining benefit from government project.

At the time of personal approach, 12 FPR participants said to field research assistant that they would be out of FPR project if local elite took part in it. Their request had been disclosed informally to field research assistant because they were still fearful to say it in four formal meeting with local elite. Conversely, in the situation local elites in Polutan Kulon and Polutan Wetan said that they had desired to join in the FPR projects. The local elites assumed that the FPR project was similar to governmental project which could provide them huge benefits so that they had to join in the FPR project.

Due to the dilemma condition and negative role of local elite from previous government project, the field research assistant had used personal approach and intensive negotiation to the local elite in order not to involve in the FPR project. From the long negotiation, the field research assistant could provide the local elite understanding of smaller benefit of the FPR project than governmental project. The local elites eventually had accepted the understanding and decided to ignore the FPR project.

Local elites are actors who have superior social, political or economic status in rural community groups so that they have role as leader to control and influence decision-making in development process (Post 2008). In theory of leadership (Wang and Thompson, 2006), the role of local elites could be negative because their decision making in development process have huge benefit for them and pose negative reaction from members of rural community groups. This statement was similar to finding on the role local elites who controlled government project in development process in Polutan kulon and Polutan Wetan. Scholars and practitioners also suggest that governments or other organizations should account for the roles and interests of local elites when beginning with community-based development projects (Dasgupta and Beard, 2007; Fritzen, 2007; Liu et al., 2016; Platteau, 2004). Furthermore, when the suggestion is 
implemented, smallholder farmers as one of object in community-based development projects are able to escape from some major problems such as insufficient farm income (Palaniswamy and Krishnan, 2012). Vietnam government as exemplary case has addressed national food insecurity by maximizing development projects to smallholder farmers and minimizing negative role of local elite (FAO, 2013). Therefore, the second lesson-leaned of FPR projects was to minimize negative role of elite local by identifying their leadership in previous government project.

\subsubsection{Maximizing positive role of local elite}

In condition before taking part in FPR project, both 12 FPR projects and 6 FPR nonparticipants certainly sold little surplus of rice production to local wholesaler after rice production met their household rice consumption. This selling activity was obligatory to them because cost of input agriculture such as rice seed and chemical fertilizers had to be paid to local wholesaler after harvest time. The obligation bred their dependence on using the agricultural inputs on local wholesaler. In addition, local wholesalers who control market were local elites so that 12 FPR projects and 6 FPR non-participants frequently communicated and had relationship with them. The relationship among wholesalers and 12 FPR projects as well as 6 FPR nonparticipants was referred to patron-client relationship. Further, the wholesalers were patron, while 12 FPR projects and 6 FPR non-participants were clients. Based on information from 12 FPR participants and 6 FPR non-FPR participants, the local wholesaler was one of local elites operating fair profit when buying rice production from them. Thus, they had better relationship than other local elites.

12 FPR participants expressed that after they had accepted to join FPR project and negative role of local elites in development projects could be minimized, field research assistant with them had intensively discussed to decide solution to implement on their farmland. In initial process of discussion, 12 FPR participants would cancel their participation in FPR project because agricultural input, rice seed of Situpatenggang, embraced new variety of rice and local wholesalers in their villages did not buy it. In further discussion, field research assistants had explained a detailed market and advantages of Situpatenggang. During the explanation, field research assistant had showed sample of production from Situpatenggang rice to be tasted by 12 FPR participants. After understanding potential market of Situpatenggang rice and tasting it, 12 FPR participants had almost re-confirmed to join in FPR project as they could eat better taste and quality of rice than common rice. However, they still worried as local wholesalers still did not buy Situpatenggang rice.

With regard to remaining issue on local trader, field assistant research had held formal discussion with 12 FPR participants and three local wholesalers. In this discussion, 12 FPR participants were active to communicate with three local wholesalers and helped field research assistant to convince good taste of Situpatengang rice. Subsequently, local wholesalers were interested in buying it because their reaction to Situpatenggang rice was similar to 12 FPR participants. In spite of demanding for much effort to sell production from Situpatenggang rice, three local wholesalers facilitated by field research assistant had used new strategy of marketing successfully. The strategy was to sell rice production from Situpatenggang to their family and friends in city. The strategy continued to be used by three local wholesalers until now. Furthermore, according to three local traders, they were difficult to fulfill demand for large number of rice production from Situpatenggang while only 12 FPR participants produced it.

Since long process of discussion to ensure participation of 12 FPR participants occurred, local wholesalers who controlled economic activities in villages significantly influenced their decision making to take part in FPR project. In theory of leadership (Wang and Thompson, 2006), the role of local wholesalers as local elite managing economic activities was positive because their decision making to buy Situpatengang rice had benefit for 12 FPR participants and them. Further, their decision making brought 12 FPR participants to ensure their joining in FPR project. This analysis was supported by Scott (1972) describing that relation between local wholesalers as patron and smallholder farmers as clients is constantly profitable for each other because patron demand for agricultural production while clients are able to meet their daily need besides food consumption from patron. Another previous study on lessonlearned from FPR project also emphasize that economic aspect had to be considered in order to achieve successful outcome (Johnson et al., 2003; Hoffmann et al., 2007). Furthermore, upland smallholder farmers in some areas has transformed subsistence crops into commercial 
crops such as tobacco (Boomgaard, 2005), potato (Santoso, 2015) to be grown as they pursue only economic goals. By using theory and some previous study to analyze process of FPR project, the third lesson-learned was that although Situpatengang rice was scientifically proved to achieve a larger number of rice yields than other variety of rice (Istiqomah et al., 2012; Warda, 2011), it could be introduced and employed by participants in FPR project by maximizing positive role of local elites as local wholesalers to buy it.

\subsubsection{Implementing modified technology packages}

During field observation, 12 FPR participants still implemented technology package from the FPR project in their farmland but 6 nonparticipants practiced common farming system. 12 FPR participants mentioned that the technology package was successful product from on-farm experimentation stage in FPR project so that they were confidence to implement until now. The modified technology packages used in FPR project was result from discussion between researchers with 12 FPR participants. In the discussion, although field research assistant facilitating three researchers had provided four items being similar to technology packages in lowland rice field, 12 FPR participants had contributed one of the four items to be modified. One item modified and accepted together was to plant rice seed when implementing the Legowo $4: 1$ row system. Planting rice seeds was common farming system in upland areas because 6 FPR non-participants also practiced it without the Legowo 4:1 row system. According to 12 FPR participants, planting rice seedling like lowland rice field demanded for much water from irrigation and upland areas could not meet the water so that they proposed that planting rice seed was main and suitable component in technology packages implemented in on-farm experiments.

In response to the comparison with government project, 12 FPR participants mentioned that FPR project was the best project they had taken part. The main reason of their response was appropriate technology package received by 12 FPR participants punctually in FPR project. On the other hand, 6 FPR non-participants and 12 FPR participants said that due to inappropriate technology package and bad timing, government project caused fewer rice yields than usual rice production. For example, using new variety of rice seed was suitable in lowland rice field but unsuitable in upland farmland because the variety demanded on much water based on their assumption. Further, they had to plant the variety in different time from their common plating time. This negative response from government project emphasized that upland smallholder farmers needed appropriate technology package by discussing with government representative before implementing it in further project so that upland smallholder farmers could assist the governments to accomplish their target such as national food security.

In order to achieve good outcome, Roger (2003) describes that innovation diffusion such as adoption of technology package for smallholder farmers in FPR project go through process consisting five stages: (1) knowledge, (2) persuasion, (3) decision, (4) implementation, and (5) confirmation. In regard to this theory, modified technology packages as one of result in FPR project also went through the process. Some activities performed by 12 FPR participants in stage of problem identification of FPR project had brought them to understand that technology package was important for them. This reflected knowledge stage in process of innovation diffusion. Technology packages passed persuasion and decision process because in stage of searching solution 12 FPR participants had agreed to adopt it after their proposal to modify had accepted together. When technology package had been applied on farm experimentation, it could be represented as implementation stage of innovation diffusion. After harvest time, modified technology package passed confirmation stage as 12 FPR participants had evaluated it in the end stage of FPR project. Besides analysis based on theory of innovation diffusion, Selener (1997) emphasize that the four stages in FPR could create and develop appropriate technology package in farmland so that farmers can replace common farming system into it. For this analysis of process in FPR project, it could be drawn that implementing modified technology packages as successful product of innovation diffusion was the fourth lesson-learned.

\section{Conclusion}

Upland smallholder farmers are one of key actors to achieve food security in Indonesia as they cultivate large number of existing farmland. However, Indonesia government have constantly ignored them to receive projects so that remaining 
low rice yields and insufficient farm income posing their gradual disappearance can not be addressed and national food insecurity has been arisen. One of alternative efforts to address this condition is participatory action research project with upland smallholder or FPR project conducted by Faculty of Forestry in UGM from 2016 to 2018. Result of the FPR project brought 12 upland smallholder farmers could increase rice production and farm income.

In addition to provide positive impact to the 12 upland smallholder farmers, the lesson-learned from process of the FPR projects could be valuable information especially for Indonesia government to begin project with upland smallholder farmers. In this study, there were four points of lesson-learned including; (1) finding a responsive smallholder farmer group; minimizing negative role of local elite; (3) maximizing positive role of local elite; (4) implementing modified technology package.

\section{Acknowledgment}

We acknowledge that key information and funding provided by Laboratory of Ecosystem Complex Process Faculty of Forestry Universitas Gadjah Mada are significantly support us. We appreciate 18 upland smallholder farmers in Wonogiri regency for their great enthusiasm and hard work on discussing with us.

\section{Reference}

Agus, F and Irawan. 2006. Agricultural land conversion as a threat to food security and environmental quality. Indonesian Agricultural Research and Development Journal. 25:3.

Alexandratos, N. and Bruinsma, J. 2012. World Agriculture towards 2030/2050: The 2012 Revision. ESA Working Paper No. 12-03. Italy. Rome.

Asian Productivity Organization. 2004. Sustainable Farming Systems in Upland Areas (p. 7). Jepang. Tokyo.

Bakar, B.A., Azis, A., Yusriani, Y., Idawanni., Andriani, Bubu, Y.G., Rosa, E., and Fachruddin. 2019. The analysis of selection of upland rice variety in East Aceh District. In The 1st International Conference on Agriculture and Bioindustry 2019 (pp. 1-7). Aceh, Indonesia. Agriculture Faculty. Universitas Syiah Kuala.
BB Padi. 2018. Padi Lahan Kering Dataran Tinggi. Retrieved from http://bbpadi.litbang.pertanian.go.id/index. php/info-berita/info-teknologi/varietasrindang-1-dan-rindang-2-tahan-naungandan-kekeringan.

Dolinska, A., Oates, N., Ludi, E., Habtu, S., Rouger, J-E., Sanchez-Reparaz, M., Mosello, B., Yazew, E., Kifle, M., Fissehaye, D., Aregay, G., Tamele, F.H., Barbara, G., and D'aquino, P. 2018. Engaging Farmers in a Research Project. Lesson Learned from Implementing the Community of Practice Concept in Innovation Platforms in Irrigated Schemes in Tunisia, Mozambique and Ethiopia. Irrigation and Drainage. 69: 38-48.

Boomgaard, P. 2005. Maize and Tobacco in Upland Indonesia, 1600- 1940. In Li, M. T. (Ed) Transforming the Indonesian Uplands Marginality, Power and Production (pp 4180). London: Routledge.

Chakraborty, M., Haider, M. Z and Rahaman, M. M. 2015. Socio-Economic Impact of Cropland Agroforestry: Evidence from Jessore District of Bangladesh. International Journal of Research in Agriculture and Forestry. 2:11-20.

Dasgupta, A and Beard, V.A. 2007. Community Driven Development, Collective Action and Elite Capture in Indonesia. Development and Change 38(2): 229-249 (2007).

Fan, S., J. Brzeska, T., Olofinbiyi. 2015. The Business Imperative: Helping Small Family Farmers to Move up or Move Out. Food Policy Report 2014-2015. International Food Policy Research Insitute (IFPRI), Washington, D.C., USA.

FAO. 2011. FAO in The $21^{\text {st }}$ Century Ensuring Food Security in a Changing World. Rome. Italy.

FAO. 2013. The State of Food Insecurity in the World 2013, the Multiple Dimensions of Food Security. Rome. Italy.

FAO, 2014. The State of Food and Agriculture 2014: Innovation in Family Farming Food and Agriculture Organization of the United Nations. Rome. Italy. 
FAO. 2017. The future of Food and Agriculture Trends and Challenges. Italy. Rome.

Fisher, R.J. 2006. What is Action Research? An introduction to action research for community development. In Seminar on Human Resource Development through Agricultural Extension, 23-26 June 2003. Tehran. Islamic Republic of Iran.

Fritzen, S. 2007. Can the Design of CommunityDriven Development Reduce the Risk of Elite Capture? Evidence from Indonesia. World Development. 35(8): 1359-1375.

German L, Tiani A. M., Daoudi A, MutimukuruMaravanyika T, Chuma E, Jum C, Nemarundwe N, Ontita E and Yitamben G. 2012. The application of participatory action research to climate change adaptation in Africa: a reference guide. Ottawa, Canada: International Development Research Centre (IDRC). Retrieved from https://www.cifor.org/ library/4036/.

Habibie, H., Sriskandarajah, N., Packham, R.G., 2002. Participative Action Research (PAR) for Rural Community Development in South Sulawesi, Indonesia. In: Ragsdell G., West D., Wilby J. (eds) Systems Theory and Practice in the Knowledge Age. Springer, Boston, MA. https://doi.org/10.1007/978-1-46150601-0_24

Hairiah, K., S.R. Utami, D. Suprayogo, Widianto, S.M. Sitompul, Sumaryo, B. Lusiana. R. Mutia, M. van Noordwijk and G. Cadisch. 2000. Agroforestri pada Tanah Masam di Daerah Tropika Basah: Pengelolaan Interaksi antara Pohon - tanah - tanaman semusim. ICRAF. Bogor.

Hoffmann, V., Probst, Ki., and Christinck, A. 2007. Farmers and researchers: How can collaborative advantages be created in participatory research and technology development? Agriculture and Human Values 24:355-368.

Henrich, J and Mcelreath, R. 2002. Are Smallholder farmers Risk-Averse Decision Makers? Current Anthropology. 43(1):172181.

Istiqomah, N., Handoko, dan R.D. Indriana. 2012. Kajian Penggunaan Varietas Padi Gogo di Lahan Sawah untuk Meningkatakan
Produktifitas Padi di Kabupaten Bojonegara. Seminar Kedaulatan Pangan dan Energi. Fakultas Pertanian. Universitas Trunojoyo.

Huizer, G. 1997. Participatory Action Research and People Participation: Introduction and Case Studies. Sustainable Development Department. FAO. Rome. Italy.

Johnson, N. L., Lilja, N. and Ashby, A. 2003. Measuringthe impact of user participation in agricultural and natural resource management research. Agricultural Systems. 78: 287-306.

Khalil, C.A., Conforti, P., Ergin, I and Gennari, P. 2017. Defining Small-Scale Food Producers to Monitor Target 2.3. of the 2030 Ageda for Sustainable Development. Rome. FAO Statistical Division.

Las. I, 2009. Revolusi Hijau Lestari untuk Ketahanan Pangan ke Depan. Tabloid Sinar Tani. 14 Januari 2009.

Liu, Z., Müller, M., Rommel, J., and Feng, S. 2016. Community-based agricultural land consolidation and local elites: survey evidence from China. Journal of Rural Studies. 47: 449-458.

Mangilep, M.A.A. 2017. The New Technology and Purposes of Paddy Rice Production in the Upland of South Sulawesi. In 2nd International Conference on Accounting, Management, and Economics 2017. Advances in Economics, Business and Management Research, Volume 40. Atlantis Press.

Marzin, J., Bonnet, P., Bessaoud, O and Ton-Nu, O. 2016. Study on Small-Scale Family Farming in the Near East and North Africa Region Synthesis. Food and Agriculture Organization of the United Nations (FAO). Regional Office for the Near East and North Africa. Cairo. Egypt.

McHugh, F. T-L. and Kowalski, K. C. 2009. Lessons Learned: Participatory Action Research with Young Aboriginal Women A Journal of Aboriginal and Indigenous Community Health. 7(1).

Mendez, V.E., Caswell, M., Gliessman S.R., Cohen, R. 2017. Integrating agroecology and participatory action research (PAR): 
lessons from Central America. Sustainability 9:705

Mutsaers, H. J. W. 2007. Smallholder Farmers, Farmer, Scientist. A Chsronicle of Tropical Agricultural Science in the Twentieth Century (p.386). Netherland: the Library of Congress.

Mwaseba, D. L., Kaarhus, R., Johnsen, F. H., Mattee, A. Z., Samwel, Z., Mvena, K and Eik, L. O. 2014. Empowering farmers? Collaborative research at Sokoine University of Agriculture, Tanzania. Development in Practice. 25(3): 347-359.

Najeb, S., Sheikh, F. A., Parray, G.A., Shikari, A. B., Zaffar, G., Kashyp, S. C., Ganie, M. A., and Shah, A. B. 2017. Farmers' participatory selection of new rice varieties to boost production under temperate agroecosystems. Journal of Integrative Agriculture 17(6): 1307-1314.

Nair, P. K. R. and Garrity, D. (Ed). 2012. Agroforestry - The Future of Global Land Use. New York, London: Springer Dordrecht Heidelberg.

Nugraha, A., Supyandi, D, and Heryanto, M. A. 2019. Sustainable and self-sufficient farming practices: a social perspective on action research implementation in agriculture development (a case study in Pamalayan, Garut, Indonesia). in Conference on Sustainability Science 2018. Bandung. Indonesia.

Palaniswamy., N dan Krishnan, N. 2012. Local Politics, Political Institutions, and Public Resource Allocation. Economic Development and Cultural Change. 60(3): 449-473.

Platteau, J. P. 2004. Monitoring Elite Capture in Community-Driven Development', Development and Change. 35(2): 223-46.

Ponzio, C., Gangatharan, R., and Neri, D. 2013. The potential and Limitations of Farmer participatory research in organic agriculture: A review. African Journal of Agricultural Research. 8(32): 4285-4292.

Popkin, S.L., 1979, The Rational Peasant: The Political Economy of Rural Society in Vietnam. Berkeley: University of California Press.
Post, D. 2008. CDD and Elite Capture: Reframing the Conversation, World Bank, Social Development How to Series, Vol. 3, February. Retrieved from http://wwwwds.worldbank.org/external/def ault/WDSContentServer/WDSP/IB/2008/0 3/27/000334955_20080327102322/Render ed/PDF/430830BRI001NO1ing0the0Conv ersation.pdf.

Poudel, D.D., Midmore, D.J. and West, L.T. 2000. Farmer participatory research to minimize soil erosion on steep land vegetable systems in the Philippines. Agriculture, Ecosystems and Environment 79: 113-127.

Reeves, S., Peller, J., Goldman, J., and Kitto, S. 2013. Ethnography in qualitative educational research: AMEE Guide No.80. Medical Teacher. 35(8): 1365-1379.

Rogers, E. M. 2003. Diffusion of Innovations Fifth Edition. London: FREE PRESS.

Sajogyo. 1977. Golongan Miskin dan Partisipasi dalam Pembangunan. Prisma, VI(3):10-17

Santoso, H. 2015. Bertani itu Berjudi: Ketika Mekanisme pasar Bias Spekulasi. Phd Thesis. Universitas Gadjah Mada.

Scott, J. C. 1972. Patron-Client Politics and Political Change in Southeast Asia. The American Political Science Review. 66(1):91-113.

Scott, C.J. 1976. The Moral Economy of the Peasant Rebellion and Subsistence in Southeast Asia (p. 35-54). New Haven and London: Yale University Press

Selener, D. 1997. Participatory Action Research and Social Change. Second Edition. Cornell University. New York. USA

Silalahi, H.N., Yudha, O.R., Dwiyanti, I.E., Zulvianita, D., Feranti, N.S., and Yustiana, Y. 2019. Government Policy Statement Related to Rice Problem in Indonesia, Review. Journal of Biological Science, Technology and Management 1:35-41.

Suranny, L. E., Anton Tyas, H, Arief B. Nugroho, A. T. H., Surati., \&Murniyanto. E. 2018. Ketahanan Pangan: Galur-Galur Padi Harapan Specifik Lokasi Hasil Persilangan Konvensional Menuju Penangkaran Benih di Wonogiri. Inisiasi, 7(2). 166-175. 
Suseno, D. dan Suyatna, H. 2007. Mewujudkan Kebijakan Pertanian yang Pro-Petani.jurnal Ilmu Sosial dan Ilmu Politik. 10(3):67-294.

Susilowati, S.H. dan M. Maulana, 2012. Luas Lahan Usahatani dan Kesejahteraan Petani : Eksistensi Petani Gurem dan Urgensi Kebijakan Reforma Agraria. Jurnal Analisis Kebijakan Pertanian. 10 (1) : 17 30.

Umanailo, B. M C., Yusuf, N., Tahir, A. Z. B., Bula, M., Mukaddar, M., Assagaf, F. S. S., Kubangun, H., Musa, D., N., M., Hamiru, H., Hanapi, H., Sangadji, F.,M., Yusuf, S. 2018. Economic and Survival Strategies of the Upland Rice Farmers. International Journal of Innovative Science and Research Technology. 7(3):618-622.

Wang C. S. and Thompson, L. L. 2006. The Negative and Positive Psychology of Leadership and Group Research. In Thye, S. R. and Lawler. E. J. (Ed). 2006. Social Psychology of the Workplace, Advances in Group Processes, Volume 23 (pp 31-61). United Kingdom: Emerald Publishing Limited.

Warda. 2011. Keragaman Beberapa Varietas Unggul Baru Padi Gogo di Kabupaten Banteng Sulawesi Selatan. Seminar Nasional Serealia. Balai Pengkajian Teknologi Pertanian Sulawesi Selatan.

Welker, M. 2012. The Green Revolution's Ghost; Unruly subjects of participatory development in rural Indonesia; Green revolution's Ghost America Ethnologist 39:389-406

Wolfenson, K. D. M. 2013. Coping with the food and agriculture challenge smallholders' agenda. Natural Resources Management and Environment Department. Food and Agriculture Organization of the United Nations. Roma. 